Jón EGILl Eybórsson

\title{
Um Wang Wei
}

W ang Wei王維 (701-761 e.Kr.) er eitt af helstu skáldum Tang-tímans. Hann var af aðalsættum og pótti vera ímynd hins húmaníska fræðimanns. Fyrri hluta ævinnar varði hann í dygga pjónustu við keisaraveldið en gat sér einnig gott orð sem pipa 琵琶leikari (pipa er fjögurra strengja kínversk lúta), ljóðskáld og listmálari. Á efri árum og einkum eftir hremmingar AnShi-uppreisnarinnar (安史之亂755-763) dró hann sig í hlé frá stjórnsýslu og helgaði sig listum og sjálfsrækt að búddískum sið sem hann hafði alla tíð hrifist að. Ekkert af málverkum hans hefur varðveist en prátt fyrir pað er hann talinn upphafsmaður svokallaðs Suðurhefðar-skóla í kínverskri listasögu 南宗畫之祖.

Eftir Wang Wei liggja um 370 ljóð. Hann var fyrst og fremst pekktur sem náttúruskáld og ljóð hans eru gjarnan látlaus og myndræn á yfirborðinu en búa yfir meiri dýpt og margbrotnari formgerð en virðist við fyrstu sýn. Um ljóð hans hefur verið sagt að pau lýsi fegurð náttúrunnar, en dragi einnig í efa endanlegan veruleika hennar. Óræðar og hrífandi náttúrumyndir einkenna ljóð hans en ef grannt er gád, pá leynir sér ekki að nærvera skáldsins og mannheima er jafnan meginkjarni ljóðanna. Um samband ljóðlistar hans og málverka var einnig oft sagt að ljóð hans væru jafn myndræn og málverkin hans ljóðræn. 